\title{
Three new species of Synodontella (Monogenea, Ancyrocephalidae), gill parasites of Synodontis spp. (Siluriformes, Mochokidae) from Côte d'Ivoire
}

\author{
Enoutchy F. Bouah ${ }^{1}$, Valentin N'Douba ${ }^{1}$, and Antoine Pariselle ${ }^{2,3, *}$ \\ ${ }^{1}$ Laboratory of Hydrobiology, UFR Biosciences, Felix Houphouët Boigny University, 22 BP 582 Abidjan 22, Côte d'Ivoire \\ 2 ISEM, Univ. Montpellier, CNRS, IRD, CC 065, Place Eugène Bataillon, 34095 Montpellier Cedex 5, France \\ ${ }^{3}$ Laboratory "Biodiversity, Ecology and Genome", Research Center "Plant and Microbial Biotechnology, Biodiversity and Environment", \\ Mohammed V University in Rabat, Faculty of Sciences, 4 avenue Ibn Batouta, B.P. 1014, Rabat, Morocco
}

Received 5 April 2019, Accepted 7 July 2019, Published online 25 July 2019

\begin{abstract}
Four species of Synodontella, including three new, are reported from three species of Synodontis (S. ocellifer, S. nigrita, and S. velifer) from north-western Côte d'Ivoire. Synodontella melanoptera Dossou \& Euzet, 1993 was found on the gills of S. nigrita and S. velifer and was already known from the gills of S. melanopterus in Benin and the gills of $S$. obesus and $S$. rebeli in Cameroon. The new species are Synodontella speroadotevii $\mathrm{n}$. sp. from S. nigrita (type-host), S. velifer and S. ocellifer, and Synodontella bagoueensis n. sp. and Synodontella akengboi n. sp., both from S. velifer (type-host for both), S. nigrita and S. ocellifer. The new species differ from the other species of Synodontella mainly in the morphology of their male copulatory organs (MCO): Synodontella speroadotevii has a twopart penis (one being a hollow tube and the other a flattened tube); Synodontella bagoueensis has a wide G-shaped penis with a sub-terminal opening; and Synodontella akengboi has a simple narrow J-shaped penis. Synodontella speroadotevii differs from Synodontella bagoueensis and Synodontella akengboi in the shape of the dorsal transverse bar, which shows no protuberance, and also in the morphology of the MCO. Synodontella bagoueensis differs from the other two species in that it has a dorsal transverse bar that is V-shaped and a G-shaped MCO. Synodontella akengboi differs from the two other species in having a J-shaped MCO and in the size of its ventral and dorsal anchors which, contrary to the other two species, are almost similar.
\end{abstract}

Key words: Siluriformes, Mochokidae, Synodontis, Monogenean, Synodontella, Gill.

Résumé - Trois nouvelles espèces de Synodontella (Monogenea, Ancyrocephalidae), parasites branchiaux de Synodontis spp. (Siluriformes, Mochokidae) en Côte d'Ivoire. Quatre espèces de Synodontella, dont trois nouvelles, sont signalées chez trois espèces de Synodontis ( $S$. ocellifer, S. nigrita et $S$. velifer) du nord-ouest de la Côte d'Ivoire. Synodontella melanoptera Dossou \& Euzet, 1993 a été trouvé sur les branchies de S. nigrita et $S$. velifer et était déjà connu des branchies de $S$. melanopterus au Bénin et des branchies de $S$. obesus et $S$. rebeli au Cameroun. Les nouvelles espèces sont Synodontella speroadotevii n. sp. de S. nigrita (hôte type), S. velifer et S. ocellifer et Synodontella bagoueensis n. sp. et Synodontella akengboi n. sp., tous deux de S. velifer (hôte type pour les deux), S. nigrita et S. ocellifer. Les nouvelles espèces se distinguent des autres espèces de Synodontella principalement par la morphologie de leurs organes copulateurs mâles (OCM) : Synodontella speroadotevii a un pénis en deux parties (l'une étant un tube creux et l'autre un tube aplati) ; Synodontella bagoueensis a un large pénis en forme de $\mathrm{G}$ avec une ouverture subterminale ; et Sy. akengboi a un pénis simple et étroit en forme de J. Synodontella speroadotevii diffère de Sy. bagoueensis et Sy. akengboi par la forme de la barre transversale dorsale, qui ne montre aucune protubérance, ainsi que dans la morphologie de l'OCM. Synodontella bagoueensis se distingue des deux autres espèces par sa barre transversale dorsale en forme de V et un OCM en forme de G. Synodontella akengboi diffère des deux autres espèces par son OCM en forme de $\mathrm{J}$ et par la taille de ses crochets ventraux et dorsaux qui, contrairement aux deux autres espèces, sont presque similaires.

\footnotetext{
*Corresponding author: antoine.pariselle@ird.fr
} 


\section{Introduction}

Monogeneans that infect small catfishes of Mochokidae have been the focus of several studies [2, 3, 6, 7, 10, 13] and, in Africa, only 10 species of Synodontella Dossou \& Euzet, 1993 (hereafter $S y$.) have thus far been reported from catfishes belonging to Synodontis Cuvier (hereafter $S$.)

In 1968, Paperna and Thurston [10] described Sy. synodontii (Paperna \& Thurston, 1968), the type species, from the gills of S. victoriae Boulenger in Uganda. In 1993, Dossou and Euzet [2] reported Sy. acropenis Dossou \& Euzet, 1993 from the gills of $S$. sorex Günther, Sy. melanoptera Dossou \& Euzet, 1993 from the gills of $S$. melanopterus Boulenger, and Sy. davidii Dossou \& Euzet, 1993 from the gills of S. membranaceus (Geoffroy Saint-Hilaire) from Benin and Mali. In 1995, Douëllou and Chishawa [3] described Sy. zambezensis Douëllou \& Chishawa, 1995 from $S$. zambezensis Peters from Lake Kariba in Zimbabwe. Raphahlelo et al. [13] confirmed the validity of these five species in their revision of the latter and Mbondo et al. [7] more recently redescribed Sy. melanoptera from the gills of $S$. obesus Boulenger and $S$. rebeli Holly in the Sanaga River (Cameroon). Mbondo et al. [7] also described two new species: Sy. apertipenis Mbondo, Nack \& Pariselle, 2017 and Sy. sanagaensis Mbondo, Nack \& Pariselle, 2017 from the gills of $S$. rebeli. Furthermore, Mbondo et al. [6] in 2019 reported Sy. angustupenis Mbondo, Nack \& Pariselle, 2019 from the gills of S. nummifer Boulenger, and Sy. longipenis, Mbondo, Nack \& Pariselle, 2019, and Sy. simplex Mbondo Nack \& Pariselle, 2019 from the gills of $S$. decorus Boulenger from the Boumba River (Cameroon).

The study presented herein on the gill monogeneans of mochokid Synodontis catfishes is the first carried out in Côte d'Ivoire. The fish, all caught from the Bagoué River, were S. nigrita Valenciennes, S. velifer Norman, and S. ocellifer Boulenger. We found four species of monogeneans belonging to Synodontella. One of them, Sy. melanoptera, was already known from the gills of $S$. melanopterus, S. obesus, and $S$. rebeli $[2,7]$, whereas the other three represent species new to science and are described here.

\section{Materials and methods}

Examined fish (Table 1) were caught with gillnets in the Bagoué River (north-western Côte d'Ivoire) from August 2018 to January 2019 at the following localities: Kanakono $\left(10^{\circ}\right.$ $\left.18^{\prime} \mathrm{N}, 6^{\circ} 13^{\prime} \mathrm{W}\right)$; Samorossoba $\left(6^{\circ} 21^{\prime} \mathrm{W}\right.$; $\left.9^{\circ} 52^{\prime} \mathrm{N}\right)$; Samorosso $\left(6^{\circ} 30^{\prime} \mathrm{W} ; 9^{\circ} 34^{\prime} \mathrm{N}\right)$; N'Dara $\left(6^{\circ} 24^{\prime} \mathrm{W} ; 9^{\circ} 26^{\prime} \mathrm{N}\right)$ and Guinguereni $\left(6^{\circ} 35^{\prime} \mathrm{W} ; 9^{\circ} 32^{\prime} \mathrm{N}\right)$ (Fig. 1). Fish were identified on site upon capture using the key developed by Paugy et al. [12] and their gills resected into two sections, one ventral and one dorsal, and fixed and stored in liquid nitrogen. Upon return to the laboratory, gill arches were thawed and intensely rinsed to detach the monogeneans, which were individually collected and transferred directly onto a slide in a drop of glycerin ammoniumpicrate mixture (GAP) [5]. Each specimen was covered with a coverslip and, after complete diffusion of the mounting medium, sealed with Glyceel. A microscope (Motic BA310) with an integrated camera was used for observations. Identification of monogeneans was based on the morphology and size of the sclerotized pieces of the haptor and the copulatory complex. Measurements were made as shown in Figure 2 following Dossou and Euzet [2]. All measurements (average followed in parentheses by minimum - maximum) are in micrometers $(\mu \mathrm{m})$. Types were deposited in the Muséum National d'Histoire Naturelle, Paris, France (MNHN) and the Royal Museum for Central Africa, Tervuren, Belgium (RMCA).

\section{Results}

The four monogenean species found on the fish examined (Table 1) comply with the description of members of Synodontella given by Dossou and Euzet [2] in having the following characteristics: Ancyrocephalidae; presence of three pairs of cephalic glands; ocellae present or absent. Intestinal branches united posteriorly. Haptor armed with two pairs of anchors (one dorsal and one ventral), two central bars (one dorsal, one ventral), and 14 hooks (seven pairs). Ventral hooks articulated at the lateral ends of the ventral bar and characterized by a handle traversed by a hull leading to the blade guard limit. Testis median and posterior. Vas deferens surrounding the left intestinal branch. Presence of a seminal vesicle and a globular prostatic reservoir. Simple tubular penis with accessory piece. Pre-testicular median ovary. Lateral vitelline cells. Right lateral vaginal opening. Muscular vagina not sclerotized. Presence of a seminal receptacle. Gill parasites of African Mochokidae (Siluriformes).

Three of these species are new to science and are described below. Synodontella melanoptera Dossou \& Euzet, 1993, was already known from $S$. melanopterus in Benin and $S$. rebeli and $S$. obesus in Cameroon; it is herein reported for the first time from Côte d'Ivoire from S. nigrita and S. velifer.

Table 1. The four species of Synodontella (Sy.) encountered on the three species of Synodontis (S.) examined from the River Bagoué, Côte d'Ivoire. Infection parameters given as number of parasites per host species followed by prevalence and mean intensity in parentheses; host standard length given as mean followed by $\min -\max$, in $\mathrm{cm}$.

\begin{tabular}{lccr}
\hline Host & S. nigrita & S. velifer & S. ocellifer \\
Standard length & $30(6.5-11)$ & $15(9.5-17)$ & $10(9.8-14)$ \\
\hline Parasite & & Infection parameters & $6(60 \%-0.9)$ \\
Sy. speroadotevii & $9(30 \%-0.3)$ & $10(66.7 \%-1.4)$ & $5(57 \%-1.4)$ \\
Sy. bagoueensis & $30(100 \%-11.6)$ & $14(91.7 \%-23.6)$ & $7(70 \%-8.6)$ \\
Sy. akengboi & $25(80 \%-4.7)$ & $12(75 \%-7.2)$ & 0 \\
Sy. melanoptera & $15(50 \%-6.4)$ & $5(33.3 \%-2.8)$ & \\
\hline
\end{tabular}




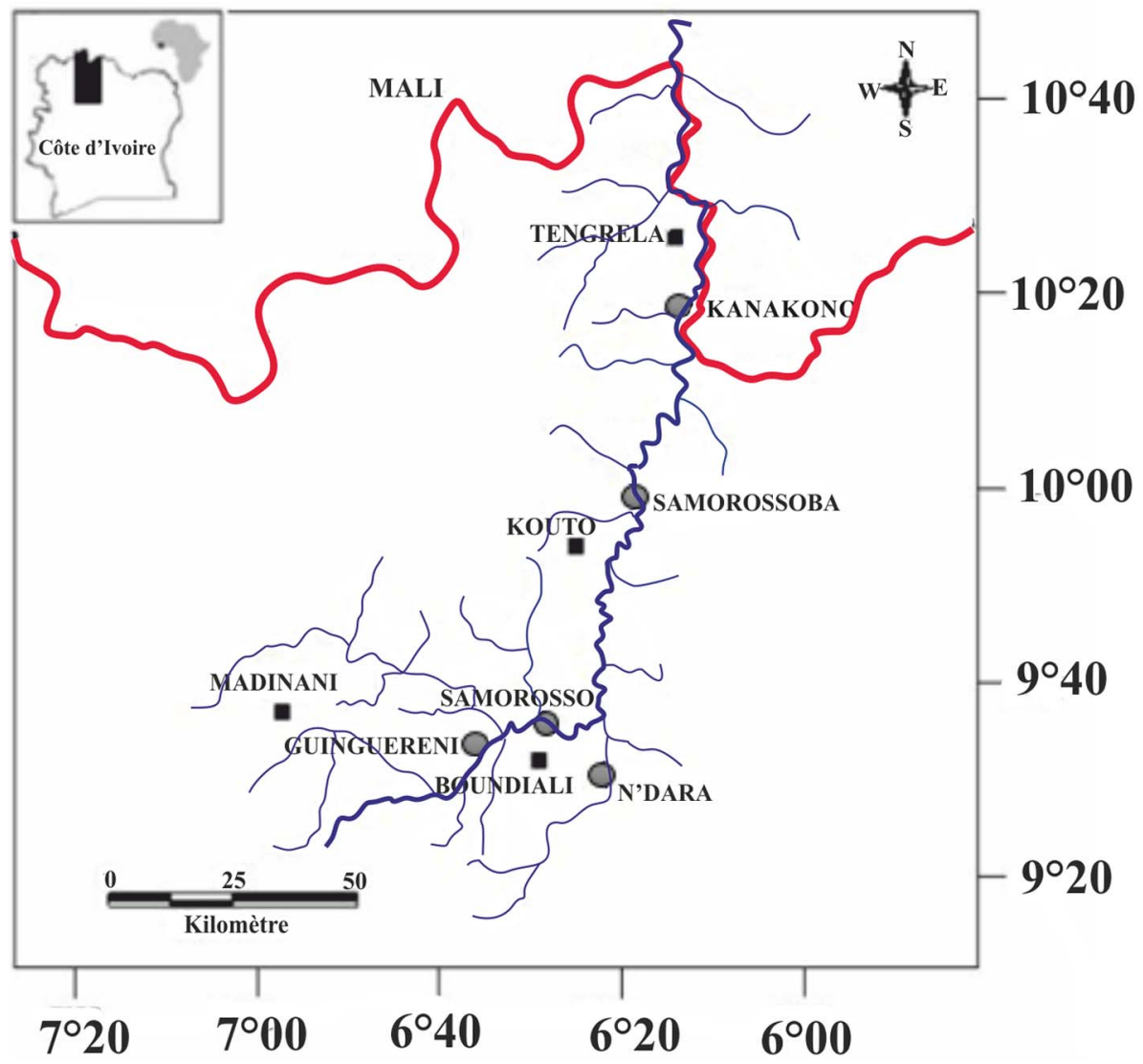

Figure 1. Locations of the different sampling stations on the Bagoué River, Côte d'Ivoire.
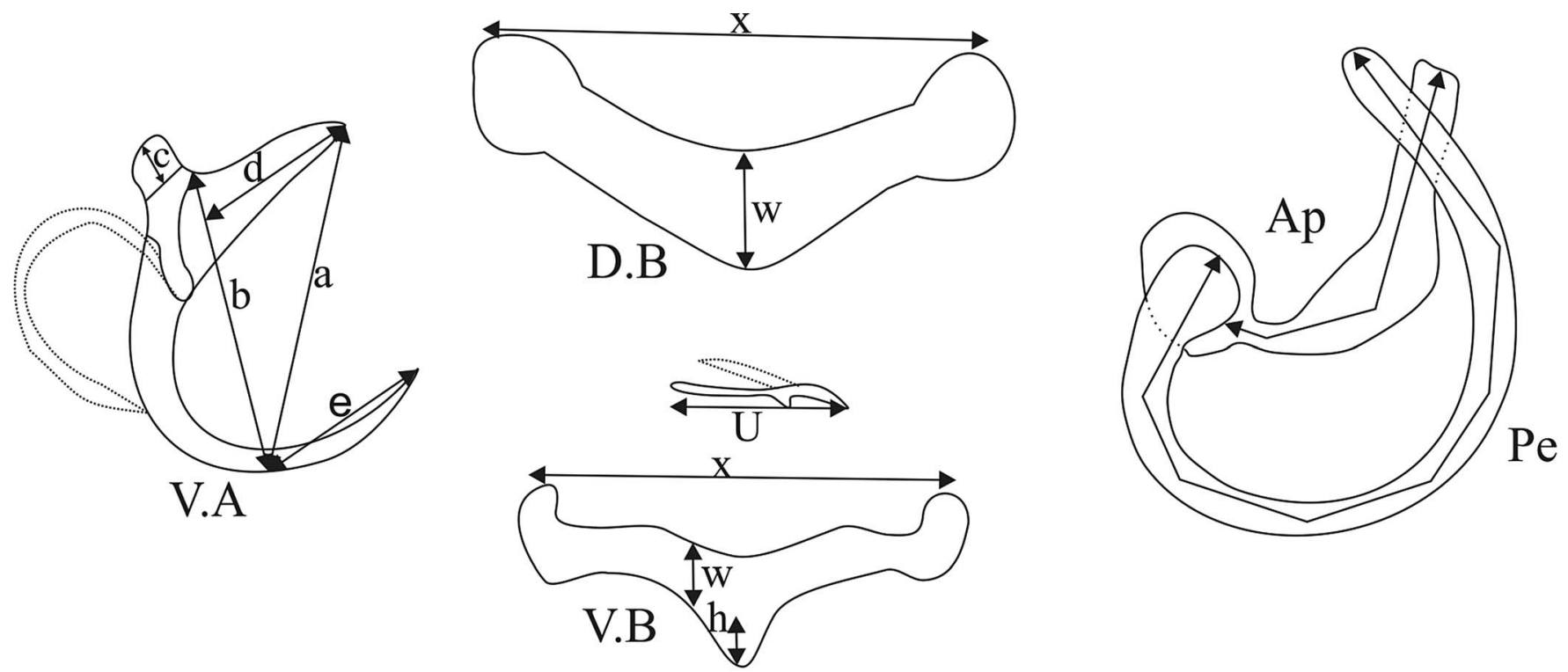

Figure 2. Measures used in this study. V.A: ventral anchor; $a$ : total length; $b$ : blade length; $c$ : shaft length; $d$ : guard length; $e$ : point length. D.B: dorsal bar; $w$ : maximum width; $x$ : length. V.B, ventral transverse bar; $h$, length of protuberance; $w$, maximum width; $x$, length. Ap: accessory piece length. Pe: penis length. $u$, length of marginal hooks. 


\section{Synodontella speroadotevii n. sp.}

urn:Isid:zoobank.org:act:B59860CC-ECF6-404D-945C4D1540AFB7BC

Type Host: Synodontis nigrita Valenciennes, 1840.

Other hosts: Synodontis velifer Norman and Synodontis ocellifer Boulenger.

Infection site: Gills.

Type locality: Bagoué River, Samorossoba, Côte d'Ivoire $\left(9^{\circ} 52^{\prime} \mathrm{N} ; 6^{\circ} 21^{\prime} \mathrm{W}\right)$.

Other localities; Kanakono $\left(6^{\circ} 13^{\prime} \mathrm{W} ; 10^{\circ} 18^{\prime} \mathrm{N}\right)$; Samorosso $\left(6^{\circ} 30^{\prime} \mathrm{W} ; 9^{\circ} 34^{\prime} \mathrm{N}\right)$; $\mathrm{N}^{\prime}$ Dara $\left(6^{\circ} 24^{\prime} \mathrm{W} ; 9^{\circ} 26^{\prime} \mathrm{N}\right)$ and Guinguereni $\left(6^{\circ} 35^{\prime} \mathrm{W} ; 9^{\circ} 32^{\prime} \mathrm{N}\right)$.

Type specimens: Holotype MNHN HEL909, paratypes MNHN HEL910-911.

Etymology: The species epithet "speroadotevii" honours Mr. Stanislas Spero-Adotevi, who has worked extensively for UNICEF in Africa.

\section{Description}

Based on 25 individuals (Fig. 3). Dorsal anchors, large, with guard longer than wide and characterized by an extremely short shaft: $a=58.4$ (52-63), $c=3.1(2-4), d=21.3(18-25)$. Long arched blade terminated by a long point: blade $b=46.3$ (42-50), $e=29$ (24-34). Dorsal transverse bar, simple and slightly curved, with swollen ends: $x=40.5$ (38-43), $w=7.7$ (6-8). Ventral anchors significantly smaller than dorsal ones, with long guard and a short shaft traversed by a hull finished by a small button in the concavity of the blade, presence of a filament at the end of the hull that covers the blade, which is strongly arched, with a long point: $a=34.2$ (31-36), $b=26.9$ (25-29), $c=3.6$ (2-6), $d=15.4$ (11-18), $e=21.1$ (16-23). Long ventral transverse bar $x=47$ (40-51) with notches at its ends but no median protuberance. All marginal hooks are small and have retained their larval morphology. The penis $\mathrm{Pe}=88.1$ (81-96), with ovoid bulb at its base, is in two parts of equal length. The first one is a simple, wide and slightly S-shaped tube with the opening at its extremity, the second one is a curved extension of the penis wall, highly sclerotized and not hollowed. Accessory piece, attached to basal ovoid bulb, is short, simple, wide and straight Ap $=34$, 7 (30-41). No sclerotized vagina.

\section{Remarks}

Synodontella speroadotevii n. sp. differs from all its congeneric species mainly in the morphology of the penis, with its opening being in the middle of its course, which is unique amongst Synodontella spp. It also differs in its ventral transverse bar, which shows no median protuberance.

\section{Synodontella bagoueensis $\mathrm{n} . \mathrm{sp}$.}

urn:1sid:zoobank.org:act:C65C6C1F-0CF0-4EE0-9F99-

\section{A280ADDC905D}

Type host: Synodontis velifer Norman.

Other hosts: Synodontis nigrita Valenciennes and Synodontis ocellifer Boulenger.
Infection site: Gills.

Type locality: Bagoué River, Samorosso, Côte d'Ivoire $\left(9^{\circ} 34^{\prime} \mathrm{N} ; 6^{\circ} 30^{\prime} \mathrm{W}\right)$.

Other localities: Kanakono $\left(6^{\circ} 13^{\prime} \mathrm{W} ; 10^{\circ} 18^{\prime} \mathrm{N}\right)$; Samorossoba $\left(6^{\circ} 21^{\prime} \mathrm{W} ; 9^{\circ} 52^{\prime} \mathrm{N}\right)$; N'Dara $\left(6^{\circ} 24^{\prime} \mathrm{W} ; 9^{\circ} 26^{\prime} \mathrm{N}\right)$ and Guinguereni $\left(6^{\circ} 35^{\prime} \mathrm{W} ; 9^{\circ} 32^{\prime} \mathrm{N}\right)$.

Type specimens: Holotype MNHN HEL912, paratypes MNHN HEL913-914.

Etymology: "bagoueensis" refers to the type locality, Bagoué River.

\section{Description}

Based on 25 individuals (Fig. 4): Large dorsal anchors $a=47.1$ (43-53), with a long guard more than six times the shaft length: $c=3.2(2-4)$. Guard long and large: $d=19.3$ (16-22). Blade long: $b=45.3$ (41-51) terminated by a long point: $e=20.1$ (18-24). Dorsal transverse bar $x=37.6$ (3245) V-shaped, thick $w=8.2(6-11)$, with swollen ends. Ventral anchors $a=26.7$ (25-30) smaller than dorsal ones, with guard longer than shaft. Guard elongated, more than three times the shaft length $d=12.9$ (9-15), $c=4.3$ (3-6). Arched blade, ending by long point: $b=22$ (20-24), $e=14.9$ (13-26). Hull, with swollen extremities, ends in the concave part of the blade. Ventral transverse bar, $x=33$ (28-37) long, $w=4.1$ (2-6) wide, with slightly rounded ends and short median expansion $h=3.1(2-5)$. All marginal hooks are small and have retained their larval morphology. The tubular penis $\mathrm{Pe}=88.2(67-92)$, consists of a wide G-shaped tube with constant diameter; the opening (hardly visible) seems to be sub-terminal. The accessory piece, Ap = $31.3(21-38)$ simple, starts from the base of the penis. No sclerotized vagina.

\section{Remarks}

Synodontella bagoueensis n. sp. is close to Sy. apertipenis in the morphology of the ventral transverse bar with rounded ends and having ventral anchors with a highly arched blade and a long guard. However, Sy. bagoueensis can be distinguished from Sy. apertipenis by: (1) the dorsal anchor with a long, wide guard and residual shaft vs short, thin guard and a marked shaft, (2) the dorsal transverse bar V-shaped, thick with rounded ends $v s$ enlarged slightly split ends, and (3) the male copulatory organ a long tube G-shaped vs long curved tube widely open from its third part.

\section{Synodontella akengboi n. sp.}

urn:Isid:zoobank.org:act:8AD2A638-7038-4EBD-B346E4F8104ED52D

Type host: Synodontis velifer Norman.

Other hosts: Synodontis nigrita Valenciennes and Synodontis ocellifer Boulenger.

Infection site: Gills.

Type locality: Bagoué River, Samorosso, Côte d'Ivoire $\left(6^{\circ} 30^{\prime} \mathrm{W} ; 9^{\circ} 34^{\prime} \mathrm{N}\right)$.

Other localities: Kanakono $\left(10^{\circ} 18^{\prime} ; 6^{\circ} 13^{\prime} \mathrm{W}\right)$; Samorossoba $\left(9^{\circ} 52^{\prime} \mathrm{N} ; 6^{\circ} 21^{\prime} \mathrm{W}\right)$; N'Dara $\left(6^{\circ} 24^{\prime} \mathrm{W} ; 9^{\circ} 26^{\prime} \mathrm{N}\right)$ and Guinguereni $\left(9^{\circ} 32^{\prime} \mathrm{N} ; 6^{\circ} 35^{\prime} \mathrm{W}\right)$. 


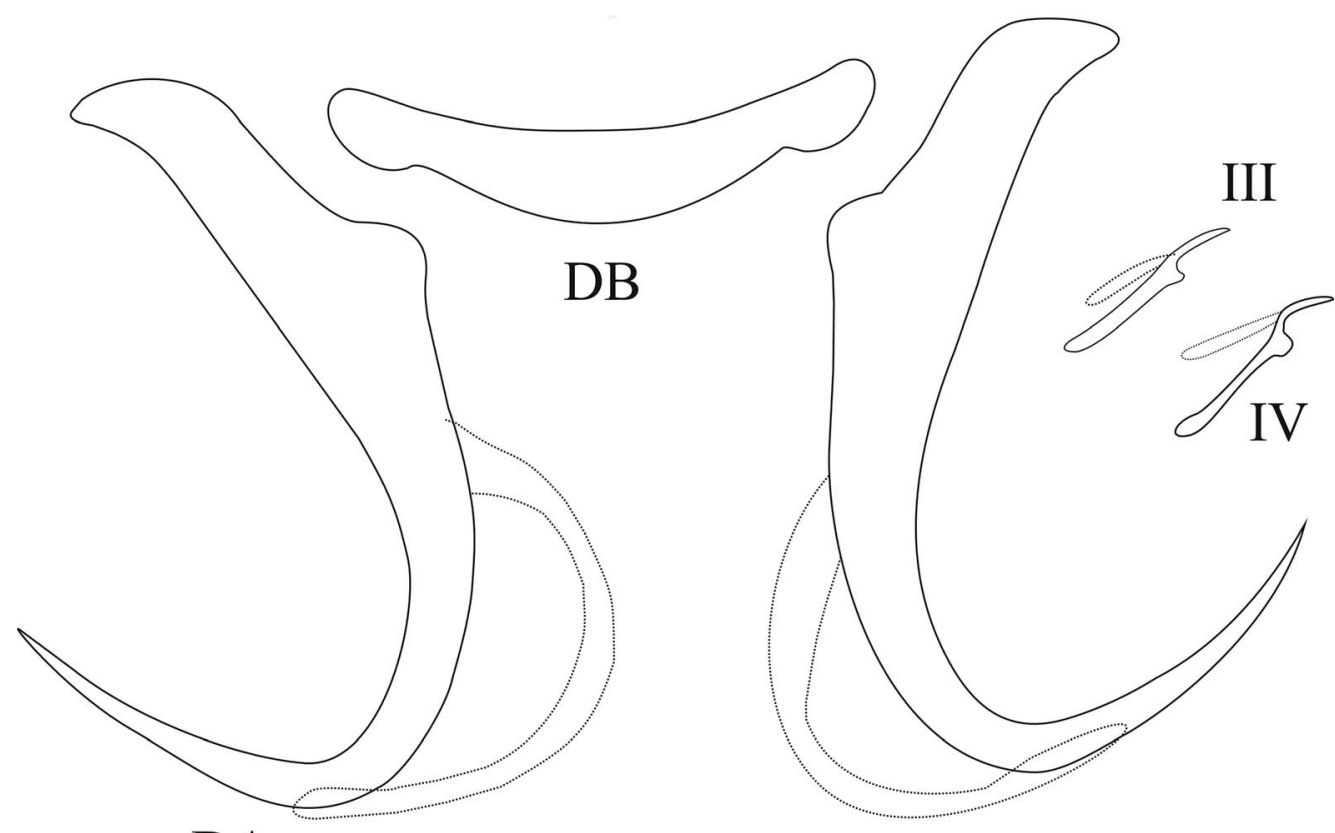

DA
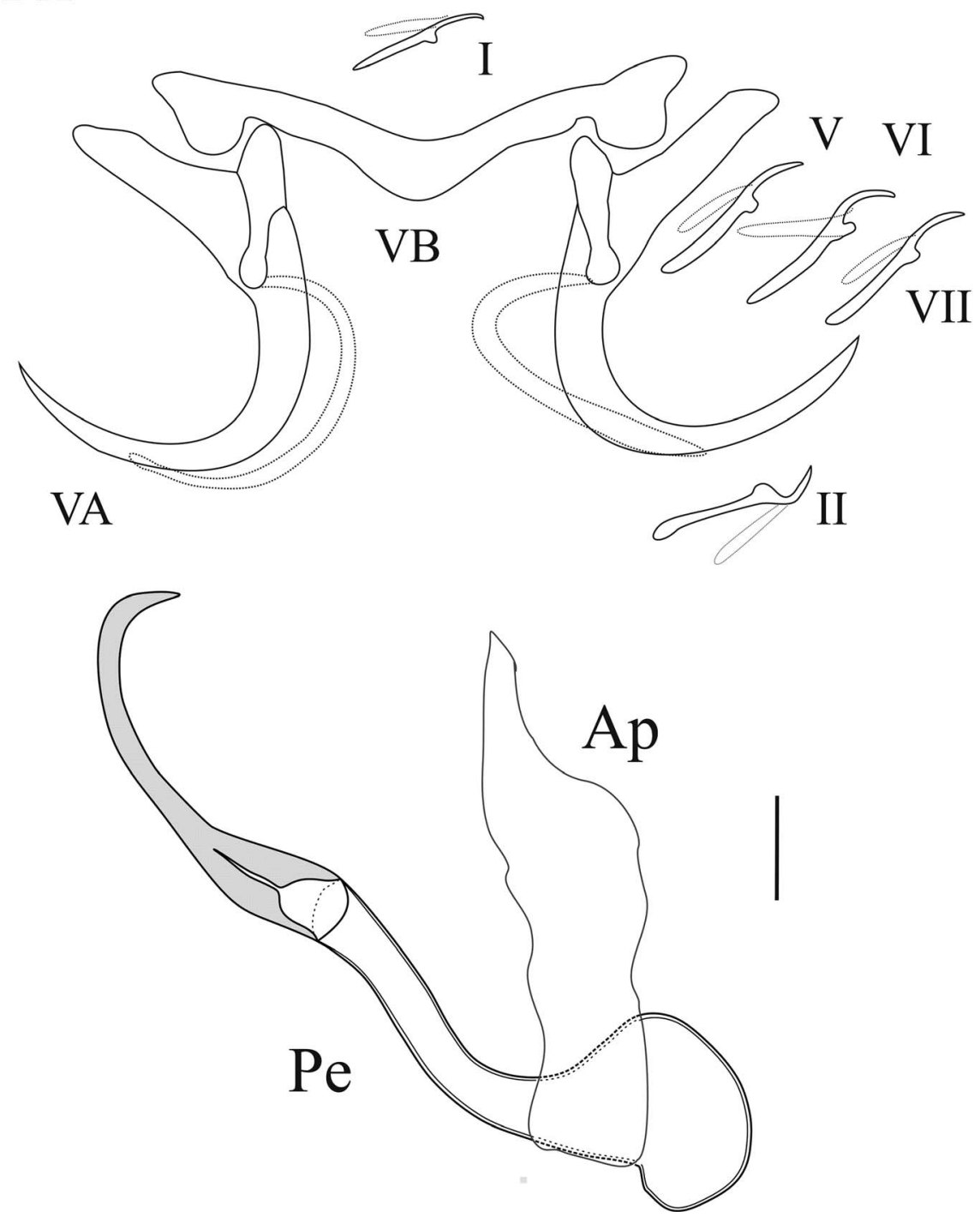

Figure 3. Hard parts of Synodontella speroadotevii n. sp. D.A: dorsal anchor; D.B: dorsal transverse bar; V.A: ventral anchor; V.B: ventral transverse bar; I-VII: marginal hooks; Ap: accessory piece; Pe: penis. Scale bar $=10 \mu \mathrm{m}$. 

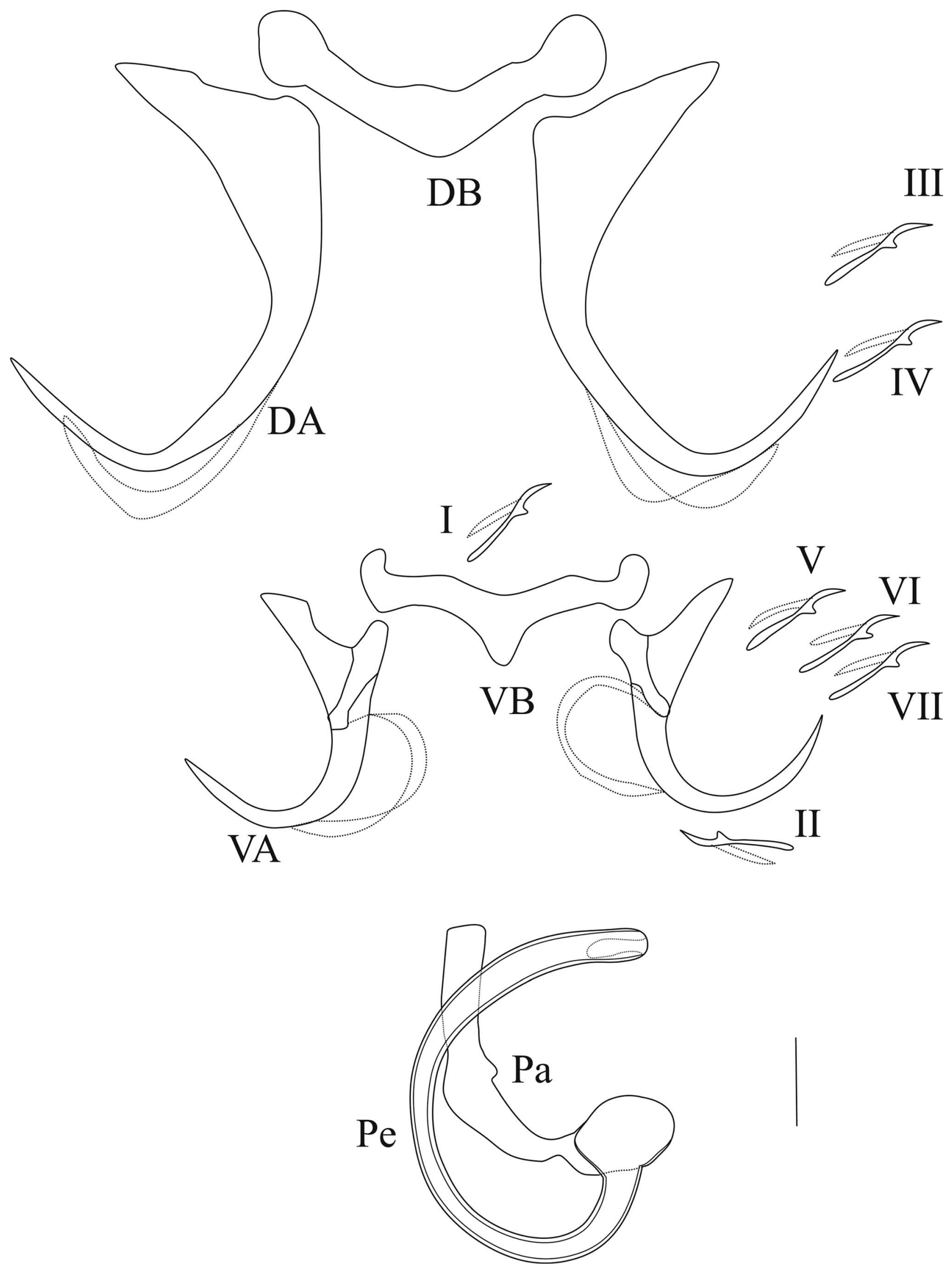

Figure 4. Hard parts of Synodontella bagoueensis: D.A: dorsal anchor; D.B: dorsal transverse bar; V.A: ventral anchor; V.B: ventral transverse bar; I-VII: marginal hooks; Ap: accessory piece; Pe: penis. Scale bar $=10 \mu \mathrm{m}$. 

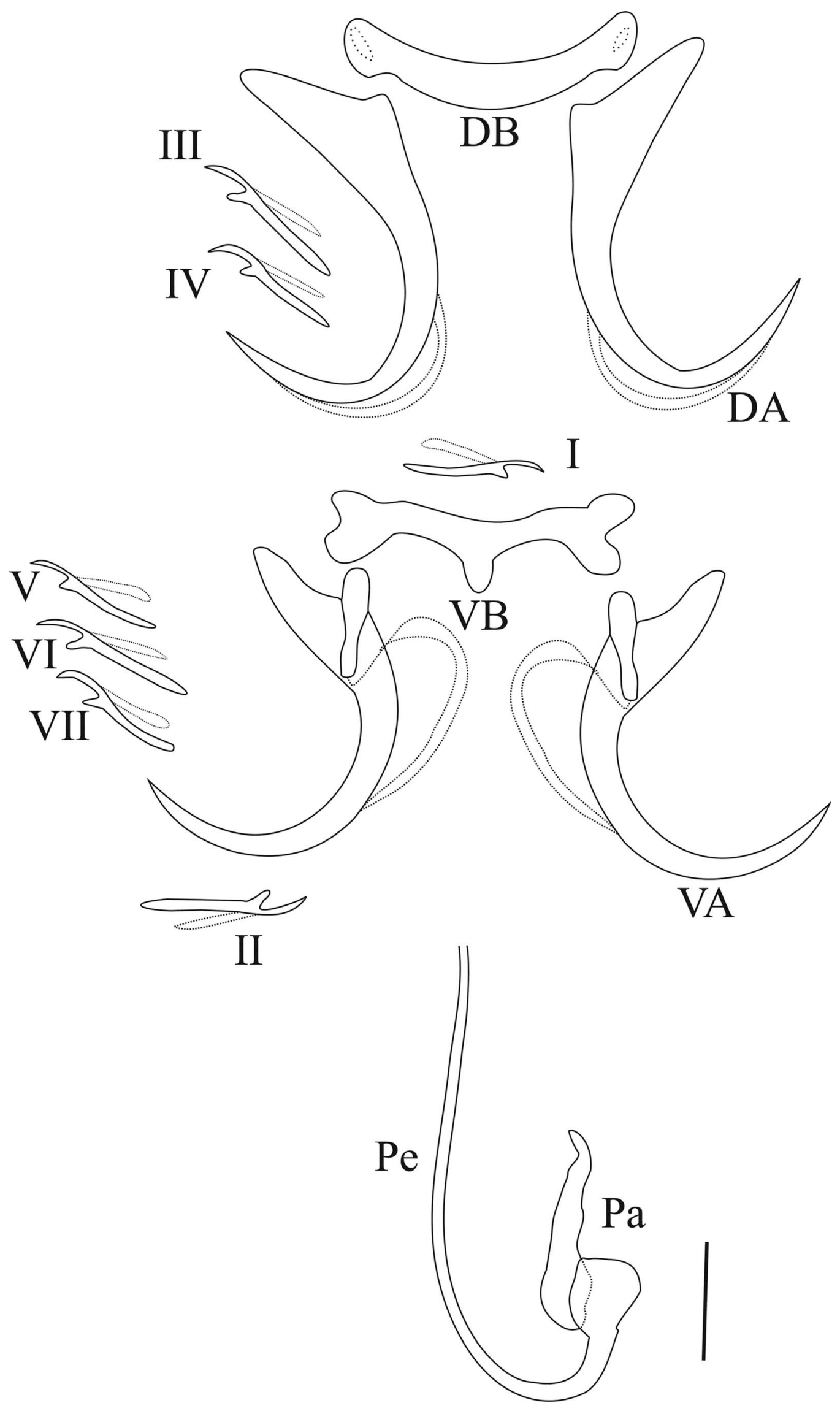

Figure 5. Hard parts of Synodontella akengboi; D.A: dorsal anchor; D.B: dorsal transverse bar; V.A: ventral anchor; V.B: ventral transverse bar; I-VII: marginal hooks; Ap: accessory piece; Pe: penis. Scale bar $=10 \mu \mathrm{m}$. 
Type specimens: Holotype MNHN HEL915, paratypes MNHN HEL916-917.

Etymology: the epithet akengboi honours Professor Gilbert Marie Aké-Ngbo of Félix Houphouët-Boigny University.

\section{Description}

Based on 30 specimens (Fig. 5). Dorsal anchors $a=36.7$ (33-39) with very short shaft and more pronounced guard, curved blade with long point $b=31.3(28-34), e=16.5$ (11-19), $d=11.7$ (9-15), $c=2.8$ (2-4). Dorsal transverse bar $x=28.1$ (25-31), simple, slightly curved with swollen ends, $w=4.4$ (3-5). Ventral anchors, $a=32$ (29-34) approximatively equal in size to the dorsal ones, with guard which is three times shaft length. Blade strongly arched with a long point, hull ended by a small button in the concavity of the blade, $b=27.3(24-30), c=4.1(2-6), d=11.8(8-15), e=17.4$ (13-21). Ventral transverse bar $x=28.1$ (25-33), with a notch at each extremity and a median expansion $w=3.4(2-5), h=4$ (2-5). All the small marginal hooks have retained their larval morphology. The penis $\mathrm{Pe}=81.6$ (57-96), tubular, thin, J-shaped, has at its base a simple accessory piece Ap $=29.4$ (18-50). No sclerotized vagina.

\section{Remarks}

Synodontella akengboi n. sp. is similar to Sy. zambezensis in the morphology of the dorsal transverse bar, which is slightly curved, and by having a ventral transverse bar with notches at both ends and a median protuberance. However, Sy. akengboi is mainly distinguishable from Sy. zambezensis by its ventral anchors and via the morphology of the male copulatory organ. The blade of the ventral anchors of Sy. akengboi is strongly arched $v s$ angled at a right angle in Sy. zambezensis. The male copulatory organ of $S y$. akengboi is a long tube $(81.6 \mu \mathrm{m})$ and is thin and J-shaped with a simple shorter accessory piece, while the male copulatory organ of Sy. zambezensis consists of a fan-shaped tube at its distal end and possesses a thin accessory piece.

\section{Discussion}

In the present study, representatives of four species of monogeneans were collected from three host species. Three of these parasites are new to science. This finding brings to 13 the known total number of species of these monogeneans belonging to Synodontella described from the siluriform Mochokidae in Africa [2, 3, 6, 7, 10, 13, 14].

These new parasites were found on the gills of Synodontis nigrita, S. velifer, and S. ocellifer obtained from the Bagoué River. This type of parasitism, with three or more conspecific species of monogeneans parasites on a host species, is well known in Siluriformes. Indeed, N'Douba et al. [8, 9] described in Côte d'Ivoire different species of monogeneans of the genera Quadriacanthus and Schilbetrema from Heterobranchus longifilis, H. isopterus, and Schilbe mandibularis. Similarly,
Mbondo et al. [7] described Sy. melanoptera, Sy. apertipenis, and Sy. sanagaensis on the gills of $S$. rebeli from Cameroon.

In this study, we also observed Sy. melanoptera on $S$. nigrita and $S$. velifer, but not on $S$. ocellifer. This monogenean has already been reported in Benin from $S$. melanopterus and in Cameroon from both $S$. obesus and $S$. rebeli $[2,7]$. Accordingly, we can assume that $S y$. melanoptera has a large geographical distribution in Africa given that it has been described from Benin, Cameroon, and Côte d'Ivoire. Likewise, this species, as is true with the other Synodontella spp., seems to have a wide host range including $S$. melanoptera, $S$. obesus, $S$. rebeli, $S$. nigrita, and $S$. velifer, and is thus stenoxenous [1]. Although $S$. nigrita, S. velifer, and $S$. ocellifer live in sympatry in the Bagoué river (at Samorossoba, Kanakono, Samorosso, N'Dara, and Guinguereni), we did not observe Sy. melanoptera from $S$. ocellifer even though, according to Paugy and Roberts [11], S. ocellifer is closely related to $S$. velifer and $S$. nigrita. The absence of Sy. melanoptera from $S$. ocellifer could be the result of a low sampling effort but can also be explained by an encounter problem in the compatibility filter [4].

Acknowledgements. The authors thank Mr. Konaté Karim, village chief of Guinguereni, and his brother Konaté Moïse for their hospitality. They would also like to thank Mr. Touré Katina, their guide and tutor in Tengrela, and the fishermen Diarrassouba Vali in Samorossoba and Yacou in Kanakono for their help. We thank Professor Vincent Connors, University of South Carolina Upstate, USA, for his assistance with proof reading and English language suggestions.

\section{References}

1. Combes C, Gavotte L, Moulia C, Sicard M. 2018. Parasitisme Écologie et évolution des interactions durables. Paris: Dunod. p. $47-53$.

2. Dossou C, Euzet L. 1993. Synodontella n. g. (Monogenea, Ancyrocephalidae) parasites de Mochokidae africains du genre Synodontis Cuvier, 1817. Journal of African Zoology, 107, 175-185.

3. Douëllou L, Chishawa AMM. 1995. Monogeneans of three Siluriform fish species in Lake Kariba, Zimbabwe. Journal of African Zoology, 109, 99-115.

4. Euzet L, Combes C. 1998. The selection of habitats among the Monogenea. International Journal for Parasitology, 28, 16451652.

5. Malmberg G. 1957. On the occurrence of Gyrodactylus on Swedish fish. Skrifter Utgivna av Sodra Sveriges Fiskeriforening Arsskrift, 1957, 19-76.

6. Mbondo JA, Nack J, Bitja Nyom AR, Pariselle A, Bilong Bilong CF. 2019. New species of Synodontella (Monogenea, Ancyrocephalidae) gill parasites of two Synodontis spp. (Pisces, Mochokidae) from the Boumba River (Congo Basin, East Cameroon). Parasite, 26, 37.

7. Mbondo JA, Nack J, Pariselle A, Bilong Bilong CF. 2017. The diversity of monogenean gill parasites of two Synodontis species (Siluriformes, Mochokidae) with the description of two new species assigned to Synodontella. Vie et Milieu - Life and Environment, 67, 75-80.

8. N'Douba V, Lambert A, Euzet L. 1999. Seven new species of Quadriacanthus Paperna, 1961 (Monogenea) from the gills of Heterobranchus longifilis and $H$. isopterus from the Ivory Coast, West Africa. Systematic Parasitology, 44, 105118. 
9. N'Douba V, Pariselle A, Thys van den Audenaerde DFE, Euzet L. 1997. Espèces nouvelles du genre Schilbetrema Paperna \& Thurston, 1968 (Monogenea, Ancyrocephalidae) parasites de Schilbe mandibularis (Günther, 1867) (Schilbeidae) en Côte d'Ivoire. Journal of African Zoology, 111, 481-487.

10. Paperna I, Thurston JP. 1968. Monogenetic Trematodes (Dactylogyridae) from fish in Uganda. Revue de Zoologie et de Botanique Africaine, LXXVIII, 284-294.

11. Paugy D, Roberts TR. 1992. Mochokidae, in Faune des poissons d'eaux douces et saumâtres de l'Afrique de l'Ouest, Tome 2, Faune Tropicale XXVIII, Paugy D, Teugels GG, Editors. ORSTOM: Paris. p. 500-563.
12. Paugy D, Lévêque C, Teugels GG. 2003. Faune des poissons d'eaux douces et saumâtres de l'Afrique de l'Ouest, Volume 2. Paris: IRD, MRAC, MNHN.

13. Raphahlelo ME, Přikrylová I, Matla MM, Theron J, LuusPowell WJ. 2016. A revised description of Synodontella zambezensis Douëllou et Chishawa, 1995 (Monogenea: Ancyrocephalidae) from the gills of Synodontis zambezensis (Siluriformes: Mochokidae) from South Africa. Helminthologia, 53, 363-371.

14. Scholz T, Vanhove MPM, Smit N, Jayasundera Z, Gelnar M. 2018. A guide to the parasites of African freshwater fishes. Abc Taxa, 18, 1-425.

Cite this article as: Bouah EF, NDouba V \& Pariselle A. 2019. Three new species of Synodontella (Monogenea, Ancyrocephalidae), gill parasites of Synodontis spp. (Siluriformes, Mochokidae) from Côte d'Ivoire. Parasite 26, 45.

\section{(-) PARASTE}

An international open-access, peer-reviewed, online journal publishing high quality papers on all aspects of human and animal parasitology

Reviews, articles and short notes may be submitted. Fields include, but are not limited to: general, medical and veterinary parasitology; morphology, including ultrastructure; parasite systematics, including entomology, acarology, helminthology and protistology, and molecular analyses; molecular biology and biochemistry; immunology of parasitic diseases; host-parasite relationships; ecology and life history of parasites; epidemiology; therapeutics; new diagnostic tools.

All papers in Parasite are published in English. Manuscripts should have a broad interest and must not have been published or submitted elsewhere. No limit is imposed on the length of manuscripts.

Parasite (open-access) continues Parasite (print and online editions, 1994-2012) and Annales de Parasitologie Humaine et Comparée (1923-1993) and is the official journal of the Société Française de Parasitologie. 